\title{
Structural contacts in subduction complexes and their tectonic significance: the Late Palaeozoic coastal accretionary wedge of central Chile
}

\author{
PETER P. RICHTER ${ }^{1}$, UWE RING ${ }^{2}$, ARNE P. WILLNER ${ }^{3}$ \& BERND LEISS ${ }^{4}$ \\ ${ }^{1}$ Institut für Geowissenschaften, Johannes Gutenberg-Universität, 55099 Mainz, Germany \\ ${ }^{2}$ Department of Geological Sciences, Canterbury University, Christchurch, New Zealand \\ ${ }^{3}$ Institut für Geologie, Mineralogie und Geophysik, Ruhr-Universität, 44870 Bochum, Germany \\ ${ }^{4}$ Zentrum für Geowissenschaften, Universität Göttingen, Göttingen, Germany
}

\begin{abstract}
Understanding the contact between the very low-grade metagreywacke of the Eastern Series and high-pressure metamorphosed schist of the Western Series in the Late Palaeozoic accretionary wedge of central Chile is fundamental for the understanding of the evolution of ancient accretionary wedges. We show the progressive development of structures and finite strain from the least deformed rocks in the eastern part of the Eastern Series of the accretionary wedge to high-pressure schist of the Western Series at the Pacific coast. Upright chevron folds of sedimentary layering are associated with an axial-plane foliation, $\mathrm{S}_{1}$. As the $\mathrm{F}_{1}$ folds became slightly overturned to the west, $S_{1}$ was folded about west-vergent open $F_{2}$ folds and an $S_{2}$ axial-plane foliation developed. Near the contact between the Western and Eastern Series $S_{2}$ represents a penetrative subhorizontal transposition foliation. Towards the structurally deepest units in the west the transposition foliation becomes progressively flattened. Finite-strain data as obtained by $R_{\mathrm{f}} / \phi$ analysis in metagreywacke and X-ray texture goniometry in phyllosilicate-rich rocks show a smooth and gradual increase in strain magnitude from east to west. Overturned folds and other shear-sense indicators show a uniform top-to-the-west shear sense in moderately deformed rocks, whereas the shear sense is alternating top-to-the-west and top-tothe-east in the strongly flattened high-pressure rocks of the Western Series near the Pacific coast. We interpret the progressive structural and strain evolution across the contact between the two series to reflect a continuous change in the mode of accretion in the subduction wedge. Initially, the rocks of the Eastern Series were frontally accreted to the pre-Andean margin before c. 300 Ma. Frontal accretion caused horizontal shortening, and upright folds and subvertical axial-plane foliations developed. At c. $300 \mathrm{Ma}$ the mode of accretion changed and the rocks of the Western Series were underplated below the Andean margin. This basal accretion caused a major change in the flow field within the wedge and gave rise to vertical shortening and the development of the penetrative subhorizontal transposition foliation. Subsequent differential exhumation was resolved gradually over a wide region, implying that exhumation was not tectonically controlled.
\end{abstract}

Fossil circum-Pacific accretionary wedges show at least two fundamentally different architectures. In the Franciscan, Aleutian and Japanese accretionary wedges higher grade rocks tectonically rest above lower grade ones (Miyashiro 1973; Suppe 1973; Cowan 1974; Platt 1975; Moore \& Allwardt 1980). For the Franciscan accretionary wedge it has been shown that the major tectonic contacts are postmetamorphic, and it was argued that they were due to late-stage out-of-sequence faulting (Platt 1975; Suppe 1978; Ring \& Brandon 1994, 1999, 2006; Bolhar \& Ring 2001; Ring \& Richter 2004). In contrast, in the Torlesse accretionary belt of New Zealand, the Olympics subduction complex of western North America and the coastal accretionary wedge of Chile, the highest grade rocks occur in the tectonically deepest levels and metamorphic grade decreases structurally upwards (Hervé 1988; Brandon \& Calderwood 1990; Mortimer 1993; Deckert et al. 2002). The transition between higher and lower grade rocks remained largely obscure.

The different architectures probably reflect changes in the mode of accretion, as illustrated with the flow-field concept of Feehan \& Brandon (1999) and Ring et al. (1999) (Fig. 1). In general, frontal accretion causes a thickening flow field characterized by converging flow lines and wholesale horizontal contraction. In contrast, basal accretion (underplating to the base of the wedge) causes a thinning flow field characterized by diverging flow lines, which indicates widespread horizontal extension in the rear of the wedge.

In the Franciscan, Aleutian and Japanese wedges the rocks were initially underplated and subsequently accretion became frontal. The shift to frontal accretion caused late horizontal shortening across the wedge and triggered out-of-sequence faulting. In the Torlesse, the Olympics and the Chilean wedges the opposite sequence of accretion seems to dominate, where initial frontal accretion was succeeded by deep underthrusting. According to the flow-line concept, there should be a temporal shift from an early relatively weak subvertical foliation in the frontally accreted rocks to a penetrative subhorizontal transposition foliation in the underplated rocks. The question remains whether the change from frontal accretion to underplating was gradual or abrupt. Accordingly, the structural contact between the lower and higher grade rocks should either be structurally transitional or a fault- or shear-zone contact.

We investigated in detail the contact between the Eastern and Western Series in the Late Palaeozoic accretionary wedge of central Chile along the Rio Maule transect $\left(35^{\circ} 25^{\prime} \mathrm{S}\right)$ to shed light on the accretionary history at the Late Palaeozoic Andean margin. We will provide quantitative evidence that the contact between the two series is structurally transitional and from this we infer that the change from frontal to basal accretion was gradual. 
a

Frontal accretion

$\mathbf{W}$

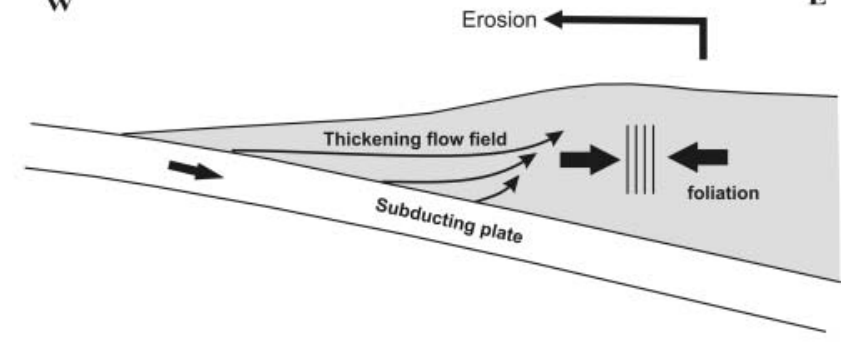

b

Basal accretion

$\mathbf{W}$



Fig. 1. Schematic illustrations of flow fields for two end-member convergent wedges (modified from Feehan \& Brandon 1999; Ring et al. 1999). (a) Distributed frontal accretion and erosion at the top of the accretionary wedge causes material flow towards the upper rear part of the wedge. The converging flow lines lead to a thickening flow field and widespread horizontal contraction. (b) Underplating coupled with erosion at the top of the wedge causes a thinning flow field characterized by diverging flow lines, which cause widespread vertical contraction and horizontal extension expressed by a subhorizontal foliation.

\section{Tectonic setting}

The Coastal Cordillera of central Chile is made up of a Late Palaeozoic subduction complex (Hervé 1988), which we refer to as the coastal accretionary belt (Fig. 2). Whereas the Late Palaeozoic subduction complex was strongly overprinted in northern Chile during continuing activity along the convergent margin, the pre-Andean subduction architecture is well preserved in central Chile (Fig. 2).

Traditionally the Eastern and Western Series are distinguished within the pre-Andean coastal accretionary belt (GonzálezBonorino 1971; Aguirre et al. 1972; Kato 1985; Hervé et al. 1988; Willner et al. 2000) as units of contrasting tectonic environments. It has been proposed that the two series represent a paired metamorphic belt (Aguirre et al. 1972; Ernst 1975; Kato 1985; Hervé 1988; Willner et al. 2005).

The structurally lower Western Series is composed of metagreywacke and metapelite of continental provenance as well as metachert, metabasite and serpentinite assemblages of oceanic origin. Maximum metamorphic conditions in the Western Series between $34^{\circ}$ and $36^{\circ} \mathrm{S}$ reached $7-11 \mathrm{kbar}$ and $380-420^{\circ} \mathrm{C}$ at 305-290 Ma (Willner 2005; Willner et al. 2005). The Western Series formed by basal accretion; subsequent exhumation rates were $0.2-0.6 \mathrm{~km} \mathrm{Ma}^{-1}$ (Glodny et al. 2005; Willner et al. 2005). In the Late Triassic, the Western Series was intruded by a few post-accretion granites (e.g. granite of Constitucion, Fig. 2).

The structurally overlying Eastern Series consists of metagreywacke and metapelite, interpreted as continent-derived, turbidite successions (Kato 1985; Hervé 1988). Oceanic derived rocks such as metachert, metabasite and serpentinite are largely absent and the lack of oceanic rocks is thought to be the most important feature for distinguishing between the two series (Godoy \& Kato 1990; Glodny et al. 2005). However, Hervé et al. (2000) and Marioth (2001) reported metabasite occurrences in structural units similar to the Eastern Series between $44^{\circ}$ and $46^{\circ} \mathrm{S}$ and at $26^{\circ} \mathrm{S}$, respectively. Thus, the absence of metabasite intercalations within the Eastern Series cannot be used as a prime criterion to distinguish between the two series.

Subduction- or accretion-related metamorphic conditions in the Eastern Series between $34^{\circ}$ and $36^{\circ} \mathrm{S}$ are completely masked by later contact metamorphism at $3 \mathrm{kbar}$ (Willner 2005). White mica in the Eastern Series along the entire Coastal Cordillera, where the high-temperature overprint does not occur, is invariably high-Si phengite and part of very low-grade mineral assemblages of the pumpellyite-actinolite facies (Willner et al. 2000). In southern Chile between $44^{\circ}$ and $46^{\circ} \mathrm{S}$, Willner et al. (2000) reported subduction- or accretion-related $P-T$ conditions of $4.5-6 \mathrm{kbar}$ and $250-280^{\circ} \mathrm{C}$. Similar $P-T$ conditions can be inferred from rocks in structural units comparable with the Eastern Series at $26^{\circ} \mathrm{S}$ (Marioth 2001).

The deformed rocks of the Eastern Series are the host rocks of the Late Palaeozoic calc-alkaline batholith at $32-36^{\circ} \mathrm{S}$, with most intrusive activity occurring around $300 \mathrm{Ma}$ (Hervé et al. 1988; Lucassen et al. 2004; Willner et al. 2005). This calc-alkaline batholith appears homogeneous over much of its extent and the intrusions were accompanied by a high-temperature overprint that increases from biotite grade to andalusite-sillimanite grade towards the batholith. Metamorphic pressure was c. $3 \mathrm{kbar} .{ }^{40} \mathrm{Ar} /$ ${ }^{39} \mathrm{Ar}$ ages from white mica that formed during the static hightemperature overprint constrain this metamorphism at 296$301 \mathrm{Ma}$ (Willner et al. 2005). These ages are in accord with older $\mathrm{K}-\mathrm{Ar}$ biotite ages ranging from 306 to $284 \mathrm{Ma}$ and $\mathrm{Rb}-\mathrm{Sr}$ whole-rock isochron ages of granites ranging from 312 to 294 Ma (Hervé 1988; Lucassen et al. 2004).

The Eastern Series and the batholith are unconformably overlain by Late Triassic to Early Cretaceous marine siliciclastic sediments and volcanosedimentary rocks. Initial deposition coincided in time with Triassic post-accretion granites in the Western Series (Fig. 2).

\section{Contact between the Western and Eastern Series}

The contact between the two series represents a long-standing problem. It has been interpreted as either a transitional structural or a tectonic contact. The contact between the Western and Eastern Series has a general north-south orientation and can be traced or inferred for more than $1500 \mathrm{~km}$ from $c .31^{\circ} \mathrm{S}$ to $c .50^{\circ} \mathrm{S}$ (Fig. 2).

Aguirre et al. (1972) and Ernst (1975) inferred that the Western and Eastern Series are largely contemporaneous and genetically associated. Ernst (1975) referred to the contact as the Coast Range Suture and argued that it represents an ancient convergent plate boundary, implying that it has plate-tectonic dimensions. However, the Pichilemu-Vichuquén Fault between the two series near Pichilemu (Fig. 2), which was taken as evidence for the suture, has been shown to be a post-accretionary brittle structure (Willner et al. 2005). Hervé (1988) followed the Ernst (1975) concept and proposed that the rocks of the Eastern 


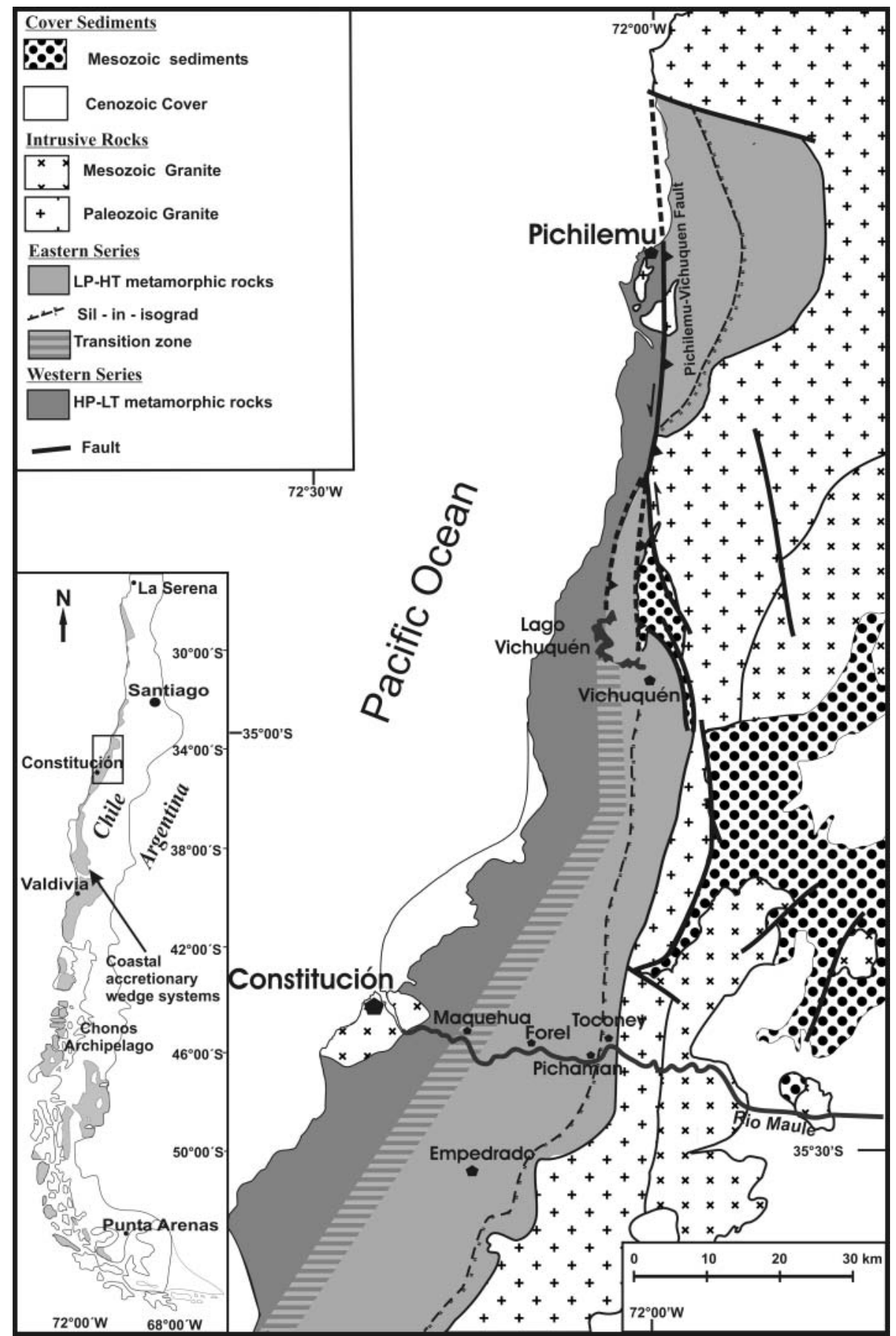

Fig. 2. Geological map of the study area; Rio Maule region studied in detail is between $35^{\circ} 15^{\prime} \mathrm{S}$ and $35^{\circ} 30^{\prime} \mathrm{S}$ (after González-Bonorino 1971; Aguirre et al. 1972; Hervé et al. 1988; Willner 2005). Inset: the coastal accretionary wedge is part of a subduction complex that fringes almost the entire length of the Pacific coastline of Chile.
Series represent a Devonian passive margin that existed before the onset of subduction, but considered the Western Series to be an accretionary wedge. Willner (2005) considered the Western Series as underplated trench sediments now resting to the west of the stationary and older Eastern Series in the retrowedge area. All these interpretations imply a major tectonic contact separating the two series.

In contrast, Godoy (1970), González-Bonorino (1971) and Hervé (1988) noted a gradual structural transition across the contact between the Eastern and Western Series at $34^{\circ}-35^{\circ} 30^{\prime} \mathrm{S}$. The only other region where a transitional contact was consid- ered in the Chilean basement is in the Chonos Archipelago at 44-46 ${ }^{\circ} \mathrm{S}$ (Davidson et al. 1987). None the less, quantitative data proving structural coherence across the contact are lacking but are critical, because structural continuity would falsify the suture hypothesis. All the above-mentioned studies inferred that the Eastern Series rocks were deposited only east and inboard of the Western Series.

From analogue experiments, Glodny et al. (2005) inferred that the tectonic, metamorphic and lithological signature of the Eastern Series rocks is characteristic of frontally accreted sediments. This is in line with the metabasite occurrences in the Eastern 
Series. Glodny et al. (2005) proposed that Eastern and Western Series rocks represent different structural units that belong to a single accretionary wedge.

The hypotheses about the contact between the Eastern and Western Series obviously have far-reaching plate-tectonic implications. Despite the importance of this issue, there remains a paucity of detailed data about ductile deformation across the contact between the series. A fundamental question is whether both series belong to the subducting plate (Glodny et al. 2005) or whether the Eastern Series is part of the overriding plate as inferred by Ernst (1975) and Hervé (1988).

In most places the contact has been strongly overprinted by post-subduction structures, which are associated either with a Late Triassic rifting event or with mid-Cretaceous and recent crustal shortening related to the modern Andean orogeny. Another problem is the generally poor exposure of the contact zone. At the northern side of the Rio Maule east of Constitucion (Fig. 3), the original contact between the Western and Eastern Series is well exposed along a railway line. In line with Godoy (1970) and Godoy \& Kato (1990), we maintain that the Rio Maule transect is most critical for addressing the nature of this contact and its tectonic significance. We studied the contact between the Eastern and Western Series in the Rio Maule transect in detail and describe the structural development and report finite-strain data across the contact.

\section{Methods}

To estimate finite strain in rocks of the Rio Maule area $R_{\mathrm{f}} / \phi$ analyses of sandstones and X-ray texture goniometry (XTG) determinations on phyllosilicate-rich rocks were carried out on 50 samples. With the $R_{\mathrm{f}} / \phi$ method (Ramsay \& Huber 1983) deviatoric strain data were obtained by measuring deformed quartz grains in thin sections in both series (44 samples). Two-dimensional strain measurements were made on $x y, x z$ and $y z$ sections $(x>y>z$, finite-strain axes) to estimate the 3D strain geometry. A least-squares best-fit ellipse was calculated for each marker outline, as well as its relative position and orientation, using the program Rfphism (written by M. T. Brandon; http://www.geology.yale.edu/ $\sim$ brandon/Software/YALEDEFM/), which is based on the method of Shimamoto \& Ikeda (1976). For $R_{\mathrm{f}} / \phi$ analysis the program determines the long and short axes of up to 50 outlined grains per section and calculates the mean aspect ratios for each investigated sample. Tectonic strains were deduced from the $\chi^{2}$ minima of the $R_{\mathrm{f}} / \phi$ analyses (Peach \& Lisle 1979). The $2 \mathrm{D}$ strain estimates were used to calculate the finitestrain ellipsoid according to the modified least-squares technique of Owens (1984).

To account for possible strain partitioning effects additional XTG measurements on phyllosilicate-rich rocks have been performed (six samples). The 3D preferred orientations of phyllosilicate grains (001planes of chlorite and muscovite) were measured at the University of Göttingen, Germany, using a reflection X-ray goniometer with $\mathrm{Cu}-\alpha$ source and an impressed voltage of $40 \mathrm{kV}$ at $30 \mathrm{~mA}$. The intensity of reflected X-rays on lattice planes of a large number of grains was measured. After setting the diffractometer to the correct Bragg angle of the analysed mineral planes, intensities were measured for different sample orientations with respect to the incoming X-ray beam. Therefore, while the diffraction angle was held fixed, the sample stage was successively tilted over $5^{\circ}$ steps. At each tilt position single intensities were measured over an azimuthal range of $360^{\circ}$ with $15^{\circ}$ intervals. For the further calculations values were cut off at a maximum tilt angle of $40^{\circ}$, to keep defocusing effects of the X-ray beam small. The intensities give a relative measure of the alignment of the observed minerals.

The XTG data have been analysed with the March model (March

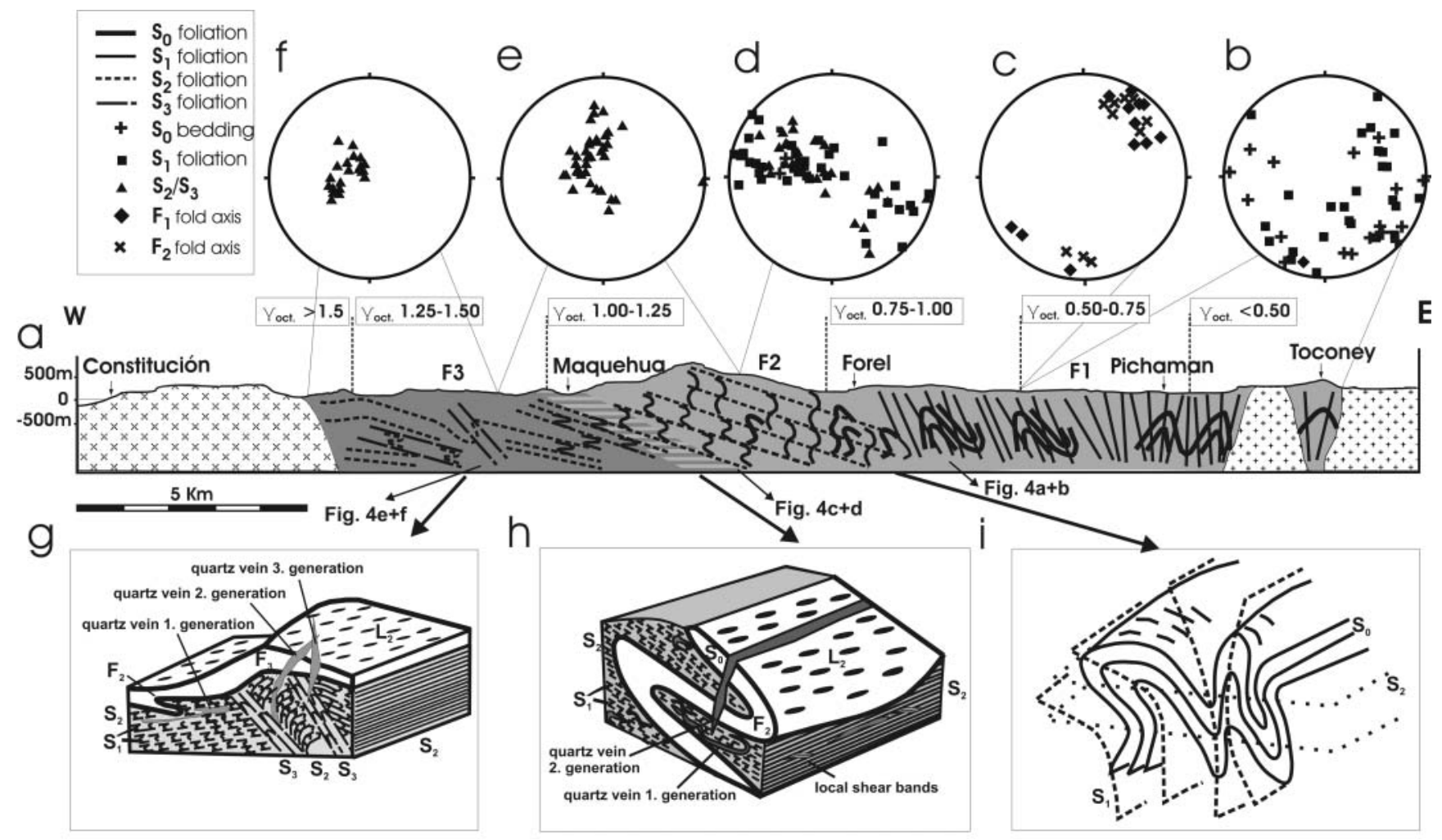

Fig. 3. (a) Progressive structural development along Rio Maule transect showing the evolution from upright folding of $\mathrm{S}_{0}$ between Toconey and Pichaman to a pervasive transposition foliation in the west. The conventional octahedral shear strain, $\gamma_{\text {oct }}$, which is a measure of the strain magnitude, increases to the west. (b)-(f) Stereograms showing orientational data for the different structures. (g)-(i) Sketches showing the structural development in detail. Localities at which photographs shown in Figure 4 were taken are also indicated. 



Fig. 4. Field and thin-section photographs from the Rio Maule transect illustrating increasing deformation from east to west (for locations refer to Fig. 3). (a) Folding of $S_{0}$ and development of an associated $S_{1}$ in the hinge of an $F_{1}$ fold. (b) Thin section from this locality depicts a weak preferred orientation of the minerals. (c) Folding of $S_{1}$ about a west-vergent $F_{2}$ fold. (d) Microphotograph shows flattened quartz grains and aligned micas forming a spaced $S_{2}$ foliation. (e) Pervasive transposition foliation with isoclinal, intrafolial folds. (f) Thin-section photograph shows a strongly preferred orientation of white mica and chlorite. 
1932), which describes the relationship between preferred orientation of platy minerals and finite strain. Strain estimations using the March method are generally in good agreement with results of strain determinations using other methods (Tullis \& Wood 1975; Wood \& Oertel 1980; Oertel 1983).

March (1932) showed that there is a relationship between preferred orientation and strain:

$$
S_{i}{ }_{i} \rho_{i}^{-1 / 3}
$$

where $S_{i}{ }_{i}$ is the principal deviatoric strain and $\rho_{\mathrm{i}}$ the pole density of the lattice planes in a certain direction, normalized to the average pole density of all orientations. The XTG method does not measure single plane orientations. Thus for our XTG measurements pole densities in March's approach are replaced by reflection intensities and equation (1) is replaced by

$$
S_{i}{ }^{6}=\left(i_{\text {net }} / i_{\text {unif }}\right)^{-1 / 3}
$$

(Oertel 1983), where $i_{\text {net }}$ is the intensity in a certain measured sample position and $i_{\text {unif }}$ is the uniform intensity of all positions.

For calculating the principal stretches $S x, S y$ and $S z$ and the principal

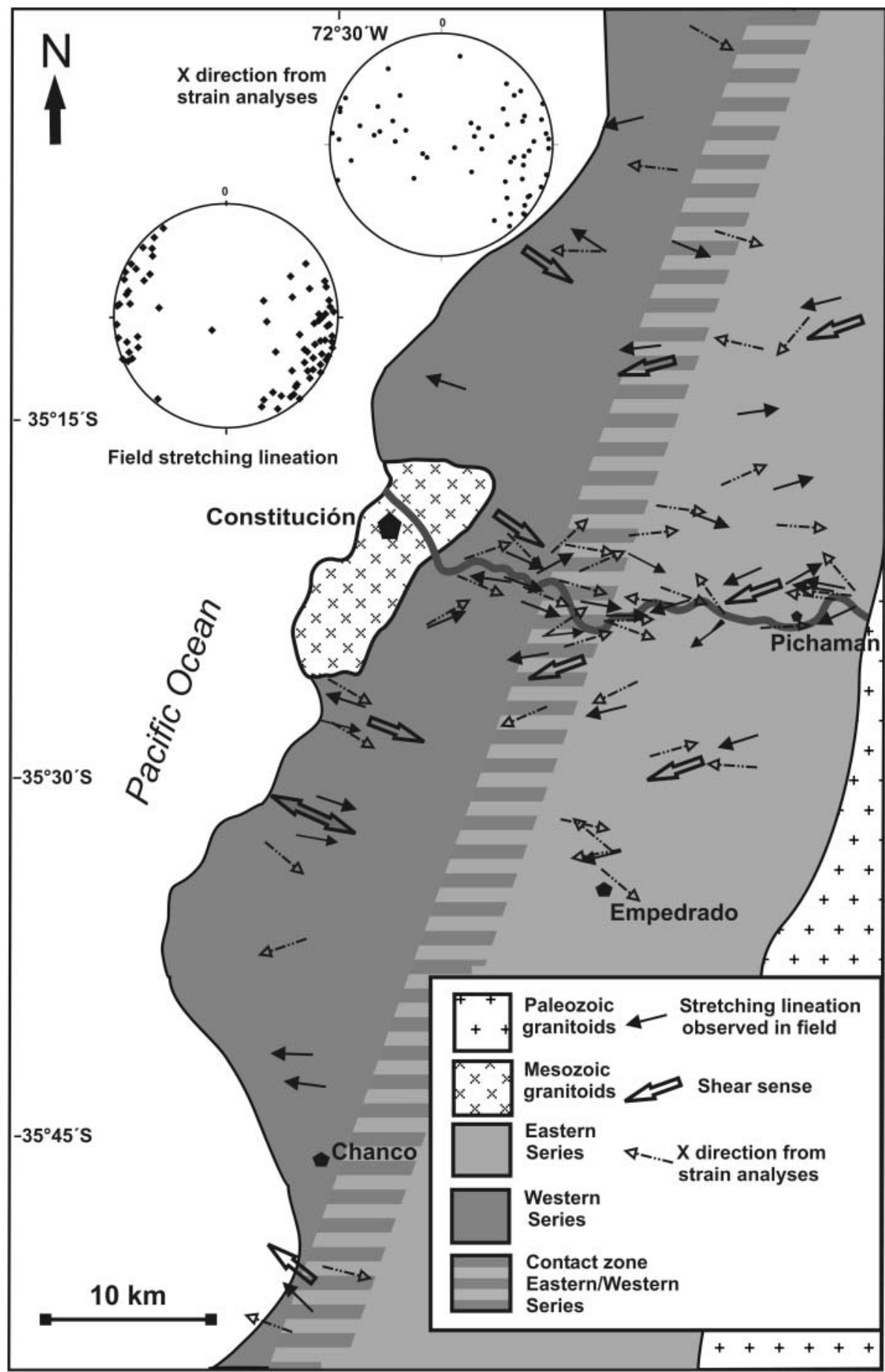

Fig. 5. Orientation of subhorizontal stretching lineations as observed in the field and $x$ directions deduced from strain analysis. Associated shear senses are top-tothe-west in the Eastern Series and alternating top-to-the-west and top-to-theeast in the Western Series. 
axial ratios $R x z, R x y$ and $R y z$ from the measured intensities, the XTGFIT program (written by M. T. Brandon) was used. This program estimates the best-fit solution for the March model using routines of Press et al. (1986). Thus it provides a measure of accuracy for the calculated March strains.

The $R_{\mathrm{f}} / \phi$ method calculates finite strain of the detrital grains, whereas the XTG method provides a measure for finite strain in the phyllosilicate matrix. To compare the results of the $R_{\mathrm{f}} / \phi$ and XTG methods the conventional octahedral shear strain, $\gamma_{\text {oct}}$, was determined. For simple shear deformation, the shear strain $\gamma$ along a specific direction can be calculated from the principal axial ratio $R$ in this direction:

$$
\gamma=\sqrt{(R-1)^{2} / R}
$$

(Ramsay 1967).

The maximum possible shear strain recorded in a rock sample is calculated from the maximum axial ratio $R x z$. The conventional octahedral shear strain can be used as a measure of the average distortion a sample underwent and is independent of strain geometry, volume change, strain path and rotational components of the deformation. It represents the integrated angular distortion experienced by material lines passing through an octahedral normal and an octahedral plane (Nadai 1950; Brandon 1995). It is given by

$$
\gamma_{\text {oct }}=\sqrt{R^{2} x y+1 / R^{2} x y+R^{2} y z+1 / R^{2} y z+R^{2} x z+1 / R^{2} x z-6 / 3} .
$$

\section{Structural evolution along the Rio Maule transect}

The structures along the Rio Maule transect show a continuous evolution from upright folding of sedimentary bedding in the east to a pronounced subhorizontal transposition foliation in the west (Fig. 3a). In the eastern parts of the cross-section east of Forel, sedimentary bedding, $\mathrm{S}_{0}$, is well preserved. Sedimentary structures include load casts, as well as graded, convolute and cross bedding. $\mathrm{S}_{0}$ is deformed by open to tight, generally upright $\mathrm{F}_{1}$ chevron folds at the $10 \mathrm{~m}$ to $100 \mathrm{~m}$ scale with axes trending NNW-SSE and plunging shallowly to the south and north. In the vicinity of the Late Palaeozoic batholith the $F_{1}$ axial planes are overturned to the east, whereas west of Pichaman they are slightly overturned to the west (Fig. 3a). In the whole eastern section the steeply dipping axial-plane foliation $\mathrm{S}_{1}$ represents the dominant planar structure (Figs 3b, c, i and 4a, b). About $500 \mathrm{~m}$ east of Forel, $\mathrm{S}_{1}$ and $\mathrm{F}_{1}$ are homoaxially refolded by open recumbent $F_{2}$ folds on a metre scale, with subhorizontal slightly east-dipping axial planes. This is associated with an east-dipping $\mathrm{S}_{2}$ foliation (Fig. 3a, d and e). West of Forel, a WNW-trending stretching lineation, $\mathrm{L}_{2}$ (Fig. 5), developed on more closely spaced $S_{2}$ planes and the $F_{2}$ folds become progressively tighter (Fig. 4c and d). Between Forel and Maquehua, quartz veining becomes prominent and a first generation of quartz veins is tightly to isoclinally folded about $F_{2}$ axes. Tightening of $F_{2}$ is associated with rotation of $\mathrm{F}_{2}$ axial planes and $\mathrm{S}_{2}$ into a shallowly east-dipping position (Fig. $3 \mathrm{~g}$ and $\mathrm{h}$ ). Shear parallel to $\mathrm{S}_{2}$ caused $\mathrm{F}_{2}$ fold hinges to be sheared out, resulting in rootless $\mathrm{F}_{2}$ folds. $\mathrm{S}-\mathrm{C}$ relationships and asymmetric clasts indicate a topto-the-WNW sense of shear (Fig. 5), which is compatible with the consistent westward vergence of $\mathrm{F}_{2}$. In highly deformed domains $S_{2}$ is progressively folded about $F_{3}$ folds with NW-SEtrending axes and subhorizontal axial planes. These folds are rather small and occur only on the decimetre to metre scale. They are associated with the development of an $S_{3}$ foliation which may dominate locally (Fig. 4e and f). Close to the supposed contact between the Eastern and Western Series near Maquehua, $\mathrm{S}_{2}$ planes in metapelite are extremely narrowly spaced at the submillimetre scale. In metapsammite $S_{1}$ is occasionally preserved and $\mathrm{S}_{0}$ can only be inferred from metapsammite-metapelite alternations.

In the rocks of the Western Series west of Maquehua the $S_{2}$ foliation becomes even more penetrative as it is rotated into a subhorizontal orientation. Folding of $\mathrm{S}_{2}$ by $\mathrm{F}_{3}$ folds produced an $\mathrm{S}_{3}$ foliation, which readily rotated into parallelism with $\mathrm{S}_{2}$ causing a penetrative $\mathrm{S}_{2} / \mathrm{S}_{3}$ transposition foliation. A ubiquitous WNW-trending stretching lineation, $\mathrm{L}_{2 / 3}$, marked by elongated quartz grains and quartz rodding, is prominent and subparallel to $F_{2}$ fold axes. Shear bands, asymmetric folds and quartz boudins yield a consistent top-to-the-WNW sense of shear near Maquehua. Quartz veins are isoclinally folded with axes subparallel to $\mathrm{L}_{2 / 3}$ and these folds are locally refolded about similarily oriented axes. Refolding produced a new crenulation cleavage, which rotated into the $\mathrm{S}_{2} / \mathrm{S}_{3}$ tranposition foliation. The pronounced transposition foliation produced $\mathrm{S}>\mathrm{L}$ tectonites. From c. $1-1.5 \mathrm{~km}$ west of Maquehua to the Pacific coast south of Constitucion the kinematic indicators associated with

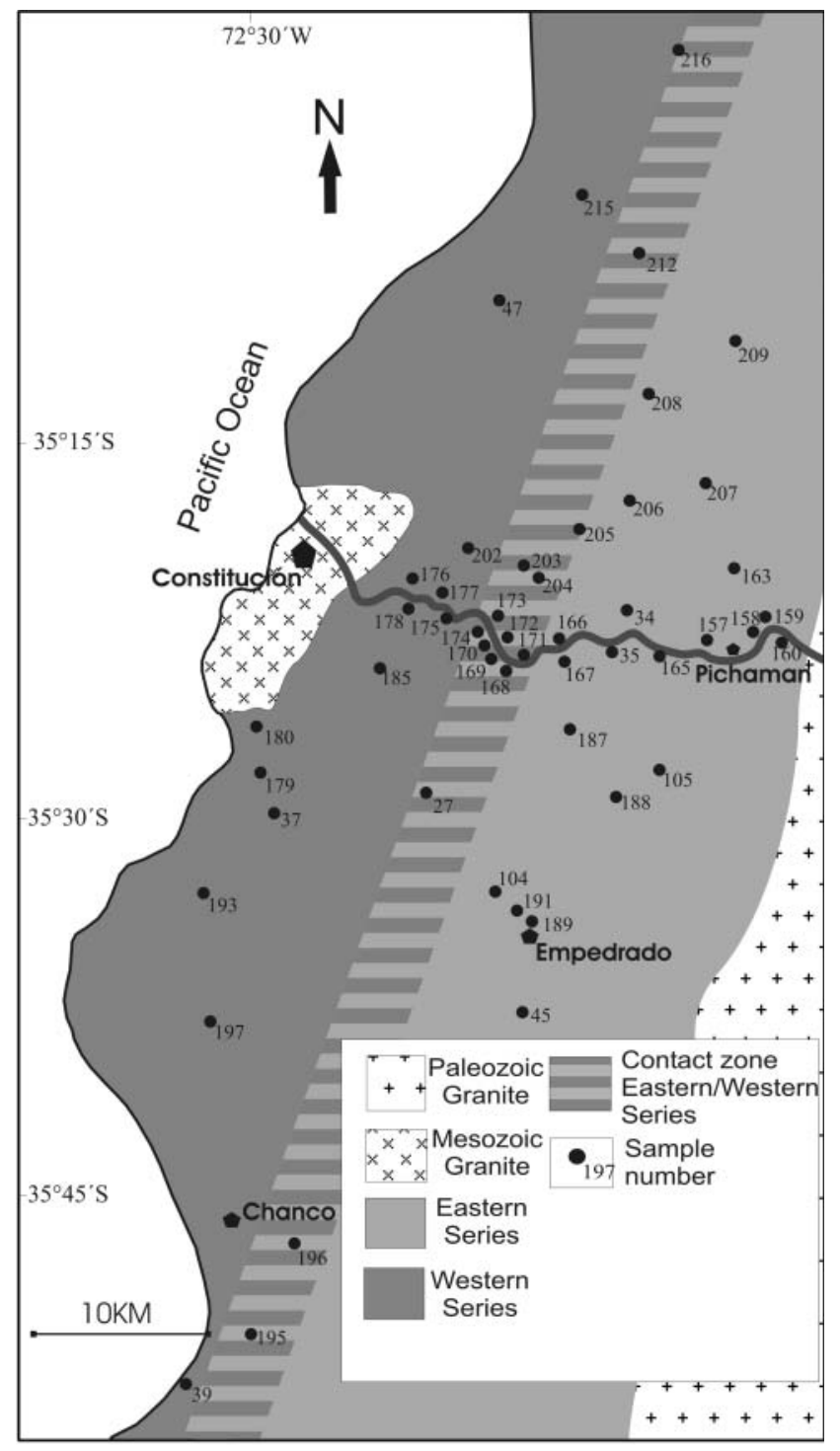

Fig. 6. Localities of strain samples in the greater Rio Maule area. 
$\mathrm{L}_{2 / 3}$ have alternating top-to-the-WNW and top-to-the-ESE shear senses. The shear bands show an evolution of early formed ductile shear bands, which are inclined at angles of $c .10-15^{\circ}$ to the penetrative foliation, to brittle-ductile shear bands, which are at an angle of $c .30-45^{\circ}$ to the penetrative foliation, and finally to brittle normal faults. Post- $\mathrm{D}_{2}$ quartz veins are also folded by $\mathrm{F}_{3}$ folds. Late quartz-filled tension gashes cut all older structures.

\section{Finite strain}

The localities of the finite-strain samples are shown in Figure 6 and the data are listed in Table 1. The maximum stretch, $S x$, ranges from 1.23 in the east to 2.50 in the west and maximum shortening, $S z$, ranges from 0.84 in the east to 0.46 in the west. In a Flinn diagram the data points are in the prolate and oblate fields (Fig. 7); phyllosilicate-rich rocks and metasandstones show

Table 1. Finite-strain data

\begin{tabular}{|c|c|c|c|c|c|c|c|c|c|c|}
\hline Sample & $x$-direction & $y$-direction & $z$-direction & $S x$ & Sy & $S z$ & $R x y$ & $R x z$ & $R y z$ & $\gamma_{\text {oct }}$ \\
\hline CH-02-27 & $92^{\circ} / 04^{\circ}$ & $182^{\circ} / 01^{\circ}$ & $272^{\circ} / 86^{\circ}$ & 1.93 & 0.75 & 0.69 & 2.58 & 2.78 & 1.08 & 1.09 \\
\hline $\mathrm{CH}-02-30$ & $325^{\circ} / 18^{\circ}$ & $218^{\circ} / 46^{\circ}$ & $71^{\circ} / 45^{\circ}$ & 1.26 & 0.56 & 0.39 & 2.24 & 3.26 & 1.45 & 1.18 \\
\hline $\mathrm{CH}-02-34$ & $292^{\circ} / 62^{\circ}$ & $207^{\circ} / 02^{\circ}$ & $116^{\circ} / 28^{\circ}$ & 1.25 & 0.98 & 0.82 & 1.29 & 1.55 & 1.19 & 0.37 \\
\hline $\mathrm{CH}-02-35$ & $120^{\circ} / 34^{\circ}(-x)$ & $209^{\circ} / 0^{\circ}$ & $301 / 56^{\circ}$ & 1.40 & 0.91 & 0.79 & 1.54 & 1.78 & 1.16 & 0.51 \\
\hline CH-02-37 & $140^{\circ} / 05^{\circ}$ & $230^{\circ} / 02^{\circ}$ & $326^{\circ} / 85^{\circ}$ & 1.93 & 0.79 & 0.66 & 2.45 & 2.92 & 1.19 & 1.10 \\
\hline CH-02-39 & $290^{\circ} / 04^{\circ}$ & $198^{\circ} / 06^{\circ}$ & $40^{\circ} / 82^{\circ}$ & 2.07 & 0.72 & 0.67 & 2.88 & 3.08 & 1.07 & 1.25 \\
\hline $\mathrm{CH}-02-75$ & $56^{\circ} / 22^{\circ}$ & $154^{\circ} / 24^{\circ}$ & $270^{\circ} / 62^{\circ}$ & 1.86 & 0.84 & 0.64 & 2.22 & 2.89 & 1.31 & 1.05 \\
\hline $\mathrm{CH}-02-83$ & $288^{\circ} / 05^{\circ}$ & $198^{\circ} / 06^{\circ}$ & $45^{\circ} / 83^{\circ}$ & 1.76 & 1.08 & 0.53 & 1.63 & 3.36 & 2.05 & 1.19 \\
\hline CH-02-92 & $282^{\circ} / 43^{\circ}$ & $180^{\circ} / 14^{\circ}$ & $76^{\circ} / 43^{\circ}(-z)$ & 1.97 & 0.76 & 0.67 & 2.59 & 2.96 & 1.14 & 1.14 \\
\hline CH-02-93 & $274^{\circ} / 56^{\circ}$ & $184^{\circ} / 03^{\circ}$ & $93^{\circ} / 33^{\circ}(-z)$ & 1.95 & 1.01 & 0.51 & 1.93 & 3.86 & 2.00 & 1.38 \\
\hline CH-02-98 & $296^{\circ} / 50^{\circ}$ & $201^{\circ} / 18^{\circ}(-y)$ & $98^{\circ} / 48^{\circ}$ & 1.37 & 0.88 & 0.83 & 1.56 & 1.66 & 1.07 & 0.47 \\
\hline CH-02-104 & $320^{\circ} / 42^{\circ}$ & $210^{\circ} / 20^{\circ}$ & $102^{\circ} / 40^{\circ}(-z)$ & 1.86 & 0.77 & 0.70 & 2.41 & 2.66 & 1.10 & 1.01 \\
\hline CH-02-107 & $103^{\circ} / 80^{\circ}$ & $192^{\circ} / 0^{\circ}$ & $283^{\circ} / 10^{\circ}$ & 1.46 & 0.91 & 0.75 & 1.60 & 1.96 & 1.22 & 0.60 \\
\hline CH-02-109 & $54^{\circ} / 63^{\circ}$ & $335^{\circ} / 0^{\circ}$ & $234^{\circ} / 26^{\circ}(-z)$ & 1.89 & 0.95 & 0.56 & 2.00 & 3.40 & 1.70 & 1.21 \\
\hline CH-04-157 & $66^{\circ} / 60^{\circ}$ & $192^{\circ} / 20^{\circ}$ & $290^{\circ} / 20^{\circ}$ & 1.26 & 0.93 & 0.59 & 1.35 & 2.13 & 1.58 & 0.67 \\
\hline CH-04-158 & $278^{\circ} / 39^{\circ}$ & $52^{\circ} / 42^{\circ}$ & $166^{\circ} / 22^{\circ}$ & 1.22 & 0.86 & 0.63 & 1.41 & 1.93 & 1.37 & 0.57 \\
\hline CH-04-159 & $276^{\circ} / 2^{\circ}$ & $11^{\circ} / 86^{\circ}$ & $184^{\circ} / 15^{\circ}$ & 1.23 & 0.79 & 0.69 & 1.55 & 1.79 & 1.15 & 0.52 \\
\hline CH-04-160 & $228^{\circ} / 76^{\circ}$ & $11^{\circ} / 12^{\circ}$ & $102^{\circ} / 6^{\circ}$ & 1.29 & 0.93 & 0.84 & 1.39 & 1.54 & 1.10 & 0.38 \\
\hline CH-04-164 & $96^{\circ} / 60^{\circ}$ & $4^{\circ} / 2^{\circ}$ & $274^{\circ} / 30^{\circ}$ & 1.25 & 1.10 & 0.64 & 1.14 & 1.96 & 1.72 & 0.62 \\
\hline CH-04-165 & $87^{\circ} / 4^{\circ}$ & $177^{\circ} / 2^{\circ}$ & $269^{\circ} / 85^{\circ}$ & 1.29 & 0.83 & 0.73 & 1.55 & 1.76 & 1.13 & 0.51 \\
\hline CH-04-166 & $88^{\circ} / 18^{\circ}$ & $126^{\circ} / 28^{\circ}$ & $327^{\circ} / 58^{\circ}$ & 1.62 & 1.11 & 0.56 & 1.46 & 2.90 & 1.99 & 1.02 \\
\hline CH-04-167 & $129^{\circ} / 25^{\circ}$ & $224^{\circ} / 6^{\circ}$ & $324^{\circ} / 64^{\circ}$ & 1.59 & 1.13 & 0.56 & 1.41 & 2.86 & 2.03 & 1.01 \\
\hline CH-04-168 & $73^{\circ} / 38^{\circ}$ & $163^{\circ} / 2^{\circ}$ & $254^{\circ} / 52^{\circ}$ & 2.16 & 0.87 & 0.63 & 2.48 & 3.45 & 1.39 & 1.28 \\
\hline CH-04-169 & $56^{\circ} / 15^{\circ}$ & $330^{\circ} / 2^{\circ}$ & $233^{\circ} / 74^{\circ}$ & 1.75 & 1.00 & 0.57 & 1.75 & 3.08 & 1.76 & 1.07 \\
\hline CH-04-170 & $126^{\circ} / 8^{\circ}$ & $34^{\circ} / 7^{\circ}$ & $264^{\circ} / 78^{\circ}$ & 1.52 & 1.26 & 0.52 & 1.21 & 2.93 & 2.42 & 1.10 \\
\hline CH-04-171 & $107^{\circ} / 3^{\circ}$ & $181^{\circ} / 16^{\circ}$ & $15^{\circ} / 70^{\circ}$ & 1.60 & 1.08 & 0.50 & 1.48 & 3.20 & 2.16 & 1.15 \\
\hline CH-04-172 & $106^{\circ} / 1^{\circ}$ & $182^{\circ} / 18^{\circ}$ & $12^{\circ} / 71^{\circ}$ & 1.60 & 1.02 & 0.53 & 1.57 & 3.04 & 1.94 & 1.07 \\
\hline CH-04-173 & $145^{\circ} / 15^{\circ}$ & $54^{\circ} / 7^{\circ}$ & $286^{\circ} / 72^{\circ}$ & 1.96 & 0.93 & 0.64 & 2.11 & 3.08 & 1.46 & 1.10 \\
\hline CH-04-174 & $113^{\circ} / 3^{\circ}$ & $22^{\circ} / 2^{\circ}$ & $266^{\circ} / 83^{\circ}$ & 1.63 & 1.09 & 0.56 & 1.50 & 2.92 & 1.96 & 1.02 \\
\hline CH-04-175 & $94^{\circ} / 22^{\circ}$ & $194^{\circ} / 20^{\circ}$ & $323^{\circ} / 60^{\circ}$ & 1.64 & 1.19 & 0.51 & 1.38 & 3.18 & 2.31 & 1.16 \\
\hline CH-04-176 & $135^{\circ} / 13^{\circ}$ & $39^{\circ} / 28^{\circ}$ & $258^{\circ} / 56^{\circ}$ & 1.67 & 1.38 & 0.43 & 1.21 & 3.87 & 3.20 & 1.55 \\
\hline CH-04-177 & $71^{\circ} / 22^{\circ}$ & $163^{\circ} / 18^{\circ}$ & $290^{\circ} / 62^{\circ}$ & 1.84 & 1.19 & 0.46 & 1.54 & 4.03 & 2.61 & 1.49 \\
\hline CH-04-178 & $113^{\circ} / 22^{\circ}$ & $10^{\circ} / 05^{\circ}$ & $260^{\circ} / 65^{\circ}$ & 1.95 & 0.88 & 0.58 & 2.22 & 3.36 & 1.51 & 1.21 \\
\hline CH-04-179 & $121^{\circ} / 10^{\circ}$ & $213^{\circ} / 8^{\circ}$ & $344^{\circ} / 78^{\circ}$ & 2.21 & 0.78 & 0.58 & 2.83 & 3.83 & 1.35 & 1.46 \\
\hline CH-04-180 & $120^{\circ} / 20^{\circ}$ & $212^{\circ} / 2^{\circ}$ & $295^{\circ} / 68^{\circ}$ & 2.50 & 0.77 & 0.52 & 3.25 & 4.82 & 1.48 & 1.84 \\
\hline CH-04-185 & $60^{\circ} / 36^{\circ}$ & $149^{\circ} / 02^{\circ}$ & $242^{\circ} / 55^{\circ}$ & 1.86 & 0.94 & 0.57 & 1.98 & 3.26 & 1.65 & 1.15 \\
\hline CH-04-187 & $244^{\circ} / 75^{\circ}$ & $12^{\circ} / 10^{\circ}$ & $115^{\circ} / 10^{\circ}$ & 1.56 & 1.04 & 0.61 & 1.50 & 2.55 & 1.70 & 0.86 \\
\hline CH-04-188 & $74^{\circ} / 25^{\circ}$ & $340^{\circ} / 10^{\circ}$ & $224^{\circ} / 62^{\circ}(-z)$ & 1.15 & 0.69 & 0.46 & 1.66 & 2.48 & 1.49 & 0.82 \\
\hline CH-04-189 & $132^{\circ} / 60^{\circ}$ & $19^{\circ} / 13^{\circ}$ & $282^{\circ} / 25^{\circ}(-z)$ & 1.27 & 0.80 & 0.52 & 1.59 & 2.42 & 1.52 & 0.79 \\
\hline CH-04-191 & $260^{\circ} / 19^{\circ}$ & $162^{\circ} / 19^{\circ}$ & $29^{\circ} / 62^{\circ}$ & 1.29 & 0.72 & 0.50 & 1.81 & 2.58 & 1.43 & 0.88 \\
\hline CH-04-193 & $130^{\circ} / 02^{\circ}$ & $220^{\circ} / 22^{\circ}$ & $30^{\circ} / 68^{\circ}(-z)$ & 2.14 & 0.82 & 0.57 & 2.62 & 3.72 & 1.42 & 1.39 \\
\hline CH-04-195 & $104^{\circ} / 36^{\circ}$ & $12^{\circ} / 04^{\circ}$ & $264^{\circ} / 52^{\circ}(-z)$ & 1.95 & 1.03 & 0.50 & 1.89 & 3.90 & 2.06 & 1.40 \\
\hline CH-04-196 & $81^{\circ} / 52^{\circ}$ & $192^{\circ} / 12^{\circ}$ & $288^{\circ} / 34^{\circ}$ & 1.76 & 1.15 & 0.50 & 1.53 & 3.55 & 2.32 & 1.29 \\
\hline CH-04-197 & $251^{\circ} / 02^{\circ}$ & $342^{\circ} / 20^{\circ}$ & $152^{\circ} / 72^{\circ}$ & 1.62 & 1.03 & 0.60 & 1.57 & 2.70 & 1.72 & 0.92 \\
\hline CH-04-202 & $47^{\circ} / 21^{\circ}$ & $142^{\circ} / 14^{\circ}$ & $261^{\circ} / 64^{\circ}$ & 2.25 & 0.87 & 0.51 & 2.59 & 4.37 & 1.68 & 1.61 \\
\hline CH-04-203 & $100^{\circ} / 34^{\circ}$ & $192^{\circ} / 01^{\circ}$ & $283^{\circ} / 54^{\circ}$ & 1.94 & 0.86 & 0.60 & 2.24 & 3.25 & 1.45 & 1.18 \\
\hline CH-04-204 & $76^{\circ} / 08^{\circ}$ & $346^{\circ} / 01^{\circ}$ & $254^{\circ} / 82^{\circ}(-z)$ & 2.08 & 0.84 & 0.57 & 2.49 & 3.63 & 1.46 & 1.34 \\
\hline CH-04-205 & $84^{\circ} / 06^{\circ}$ & $176^{\circ} / 02^{\circ}$ & $288^{\circ} / 82^{\circ}$ & 2.13 & 0.84 & 0.56 & 2.55 & 3.80 & 1.49 & 1.41 \\
\hline CH-04-206 & $98^{\circ} / 26^{\circ}$ & $201^{\circ} / 26^{\circ}$ & $312^{\circ} / 62^{\circ}$ & 1.72 & 1.03 & 0.56 & 1.66 & 3.06 & 1.84 & 1.07 \\
\hline CH-04-207 & $76^{\circ} / 65^{\circ}$ & $190^{\circ} / 11^{\circ}$ & $285^{\circ} / 22^{\circ}$ & 1.77 & 0.83 & 0.68 & 2.14 & 2.60 & 1.22 & 0.94 \\
\hline CH-04-208 & $283^{\circ} / 26^{\circ}$ & $29^{\circ} / 31^{\circ}$ & $161^{\circ} / 48^{\circ}$ & 1.94 & 1.00 & 0.52 & 1.95 & 3.74 & 1.92 & 1.34 \\
\hline CH-04-209 & $219^{\circ} / 58^{\circ}$ & $349^{\circ} / 24^{\circ}$ & $90^{\circ} / 22^{\circ}$ & 1.72 & 1.14 & 0.51 & 1.51 & 3.35 & 2.22 & 1.21 \\
\hline CH-04-212 & $106^{\circ} / 02^{\circ}$ & $16^{\circ} / 02^{\circ}$ & $262^{\circ} / 88^{\circ}(-z)$ & 1.67 & 1.19 & 0.50 & 1.40 & 3.32 & 2.37 & 1.22 \\
\hline CH-04-215 & $273^{\circ} / 09^{\circ}$ & $183^{\circ} / 07^{\circ}$ & $50^{\circ} / 79^{\circ}(-z)$ & 2.38 & 0.68 & 0.61 & 3.49 & 3.88 & 1.11 & 1.61 \\
\hline CH-04-216 & $130^{\circ} / 04^{\circ}$ & $222^{\circ} / 22^{\circ}$ & $38^{\circ} / 68^{\circ}(-z)$ & 1.95 & 0.80 & 0.64 & 2.43 & 3.06 & 1.26 & 1.14 \\
\hline CH-04-217 & $104^{\circ} / 25^{\circ}$ & $205^{\circ} / 21^{\circ}$ & $329^{\circ} / 55^{\circ}$ & 1.96 & 0.90 & 0.57 & 2.19 & 3.47 & 1.58 & 1.25 \\
\hline CH-04-218 & $301^{\circ} / 34^{\circ}$ & $207^{\circ} / 08^{\circ}$ & $102^{\circ} / 54^{\circ}(-z)$ & 2.03 & 0.75 & 0.66 & 2.70 & 3.10 & 1.15 & 1.21 \\
\hline CH-04-219 & $296^{\circ} / 05^{\circ}$ & $213^{\circ} / 42^{\circ}$ & $31^{\circ} / 48^{\circ}$ & 1.76 & 0.98 & 0.58 & 1.79 & 3.06 & 1.71 & 1.07 \\
\hline CH-04-220 & $68^{\circ} / 02^{\circ}$ & $158^{\circ} / 20^{\circ}$ & $325^{\circ} / 74^{\circ}$ & 1.76 & 0.86 & 0.66 & 2.04 & 2.69 & 1.32 & 0.95 \\
\hline
\end{tabular}




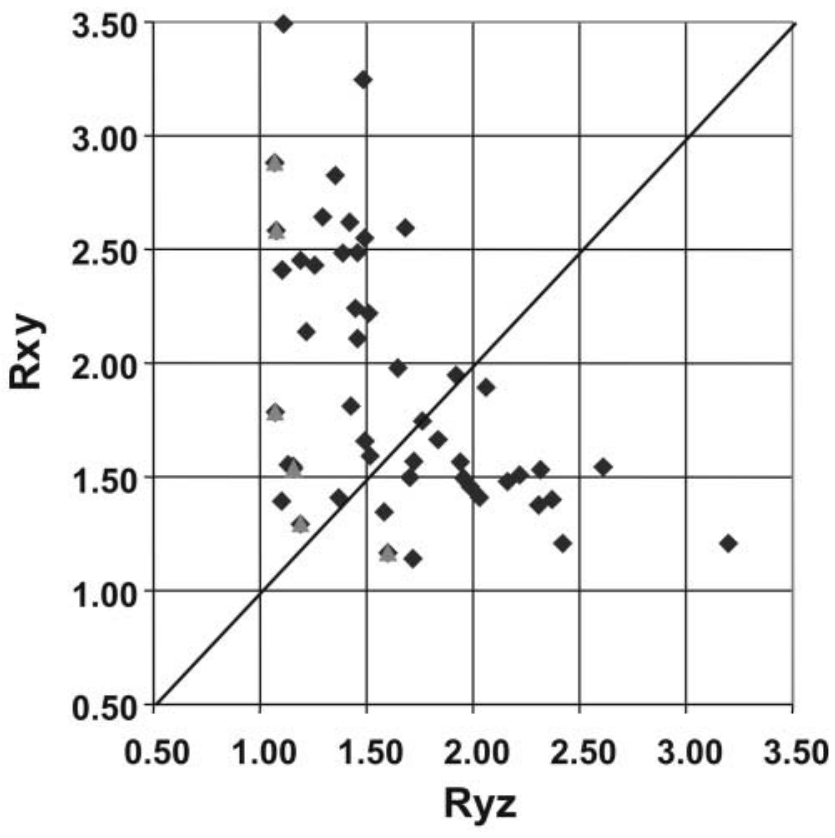

Fig. 7. Flinn diagram showing strain symmetry for $R_{\mathrm{f}} / \phi$ (diamonds) and XTG (grey triangles) data with data points split between prolate and oblate fields.

no differences in strain symmetry. In Figure 8 the conventional octahedral shear strain, $\gamma_{\text {oct }}$, has been plotted and contoured. As the principal stretches, $\gamma_{\text {oct }}$ also depicts a pronounced increase in strain magnitude from east (with values as small as 0.37 ) to west (with values up to 1.84). The least deformed samples $\left(\gamma_{\text {oct }}\right.$ $<0.75)$ are from areas of upright $F_{1}$ folding, preserved sedimentary structures and axial-plane $S_{1}$ foliation. The next contour interval of $\gamma_{\text {oct }}, 0.75-1.00$, coincides with folding of $S_{1}$ by $F_{2}$ and the incipient development of $S_{2}$. The rotation of $S_{2}$ into a subhorizontal position and the associated pervasive development of $\mathrm{S}_{2}$ takes place in the $\gamma_{\text {oct }}$ interval of $1.00-1.25$. The contact between the Eastern and Western Series coincides with $\gamma_{\text {oct }}$ values of $1.25-1.50$. In the westernmost and structurally lowermost outcrops of the Western Series, $\gamma_{\text {oct }}$ values increase to $>1.50$.

Plotting the $\gamma_{\text {oct }}$ values against distance in the east-west direction (Fig. 9) illustrates a continuous and smooth increase in the strain magnitude from east to west. It is important to note that there are no detectable breaks in $\gamma_{\text {oct }}$ values across the contact between the Eastern and Western Series.

\section{Discussion and conclusions}

We have shown that there is no structural break across the boundary between the Eastern and Western Series and that the Late Palaeozoic accretionary wedge of central Chile represents a continuous structural section. The finite-strain data fully corroborate structural continuity across the contact. We interpret this progressive structural and strain evolution across the contact between the Eastern and Western Series to reflect a continuous tectonic evolution of the accretionary wedge.

The structural development along the Rio Maule transect shows distinct changes in the style of deformation from east to west. Along with an increase in strain magnitude to the west, upright large-scale folds become progressively overturned to the west and finally become isoclinal, sheared, recumbent, smallscale intrafolial folds in the west. With increasing vertical shortening kinematic indicators change from top-to-the-west in the central part of the cross-section to alternating top-to-the-west and top-to-the-east shear sense indicators in the westernmost part of the transect (Fig. 5). We envisage that a temporal change in the mode of accretion caused this progressive structural change, which we portray using the flow-line model for accretionary wedge by Feehan \& Brandon (1999) and Ring et al. (1999) (Fig. 1).

Figure 10a shows that the rocks of the Eastern Series were frontally accreted before c. $300 \mathrm{Ma}$. Frontal accretion promoted horizontal shortening and the development of upright bedding folds. We envisage that some rocks followed a flow path that was nearer the surface than others. Therefore metamorphic processes associated with deformation in deeper parts of the wedge promoted the development of axial-plane foliations, which created the $\mathrm{S}_{0}-\mathrm{F}_{1}-\mathrm{S}_{1}$ overprinting relationships common in the eastern part of the Eastern Series. Further west in the Eastern Series $F_{2}$ and $S_{2}$ become prominent. We suggest that offscraping of water-rich trench sediments almost fully decoupled the sediments from the mafic rocks of the oceanic crust and therefore only a few imbricated metabasic rocks occur in the Eastern Series.

At c. $300 \mathrm{Ma}$ the mode of accretion changed (Fig. 10b). The rocks of the Western Series were underplated below the accretionary wedge and were metamorphosed at high-pressure conditions. Underplating caused a major change in the flow field within the wedge and gave rise to vertical shortening and the development of a subhorizontal foliation. Based on the consistent orientation of underplating-related stretching lineations (Fig. 5) and west-vergent folding, we envisage that there was a relatively high degree of coupling between the subducting and overriding plate at this stage. The lowermost rocks of the Eastern Series were affected by this relatively high degree of coupling and thus basal traction, which caused shear deformation in the lower parts of the accretionary wedge. Because of this shear the $F_{1}$ folds were successively refolded and their axial planes were overturned to the west near the contact to the Western Series. A higher degree of coupling between the downgoing plate and the accretionary wedge is also consistent with marked imbrication of mafic material from the downgoing oceanic crust.

Kinematic indicators are top-to-the-west for most of the studied transect. Only in the westernmost parts of the Rio Maule transect does the shear sense starts to alternate between top-tothe-east and top-to-the-west. The change from a monovergent to a bivergent shear sense associated with $\mathrm{L}_{2 / 3}$ coincides with an increase in the amount of underplating-related vertical shortening from east to west. We interpret the alternating shear sense to reflect a coaxial component of deformation that was superimposed on the coupling-related non-coaxial component of deformation. According to our data, a vertical shortening of $c$. $50 \%$ was needed to overcome the non-coaxial component imposed by the coupling-related basal traction.

The change in the mode of accretion can explain the progressive structural and strain evolution. We cannot decide whether the change in the mode of accretion was abrupt or whether frontal accretion gradually changed to basal accretion. However, we interpret the gradual development of the structures and strain data to reflect a gradual change. Our model implies that the early subduction-related metamorphism was continuous across the entire accretionary wedge. The sparse $P-T$ data from the Eastern Series further north and south seems to be in line with this proposition. Subsequently, the eastern part of the Eastern Series 




Fig. 8. Map showing values of the conventional octahedral shear strain, $\gamma_{\text {oct }}$, as obtained from $R_{\mathrm{f}} / \phi$ and XTG

measurements. Contouring shows an increase in strain magnitude from east to west; however, there is no abrupt increase in $\gamma_{\text {oct }}$ across the contact between the Eastern and Western Series (horizontal lines pattern).

was overprinted by a static high-temperature metamorphism related to the intrusion of the granitoids of the Early Palaeozoic magmatic arc. The contact metamorphism at c. $300 \mathrm{Ma}$ affected most of the Eastern Series and also the transition to the Western Series in the Rio Maule transect. This metamorphism affected the rocks at pressures of $c .3 \mathrm{kbar}$, indicating that the Eastern Series were in the upper crust at $c$. $10-12 \mathrm{~km}$ depth. At about the same time some of the Western Series rocks were underplated and experienced pressures of c. $9 \mathrm{kbar}(30-35 \mathrm{~km}$ depth) in the Rio Maule profile (Willner 2005). This indicates that the two events occurred at the same time and therefore they provide an estimate of the depths of the rocks of the Eastern and Western Series at this time. The rocks on which the pressure estimates were made are $c$. $20 \mathrm{~km}$ apart from each other, which is in agreement with the amount of crustal section of c. $20 \mathrm{~km}$ (as inferred from the pressure difference). This suggests that the crustal section is largely in its original Late Carboniferous configuration. Because there is not a pronounced present topographic difference in the $c$. $20 \mathrm{~km}$ horizontal distance between the locations on which the pressure estimates have been made, and there is structural 


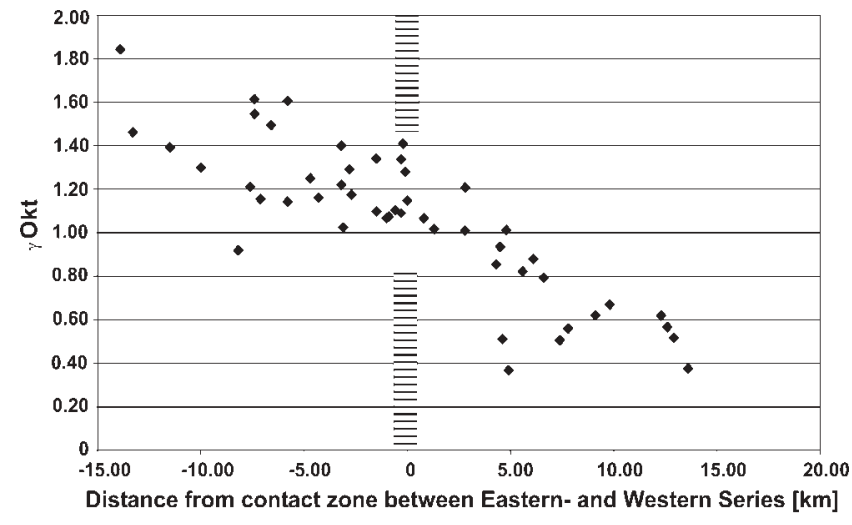

Fig. 9. Diagram showing gradual increase of the conventional octahedral shear strain, $\gamma_{\text {oct }}$, from east to west across the contact between the Eastern and Western Series (contact is indicated by vertical bar with horizontal line pattern). continuity between the two series, we envisage that the differential exhumation was resolved rather gradually over a wide region. This differential exhumation must have caused rotation about a horizontal axis of the region and implies backrotation of some $30-$ $45^{\circ}$ of earlier formed structures.

In summary, we have shown that both the Western and Eastern Series belong to the pre-Andean coastal accretionary belt of Chile and their different $P-T-t-D$ evolutions reflect differences in the mode of accretion through time. Subsequent differential exhumation did not occur along discrete faults but was resolved rather gradually over a wide region, which in turn implies that exhumation was not tectonically controlled.

This research was financially supported by the Deutsche Forschungsgemeinschaft (grants Ri538/21 and Wi875/8) and the German-Chilean BMBF-CONICYT co-operation project (Chl 01A 6A). We thank N. Mortimer and an anonymous reviewer for their comments, and $\mathrm{T}$. Needham for editorial handling. F. Hervé and E. Godoy are thanked for continuous support and advice. (a)

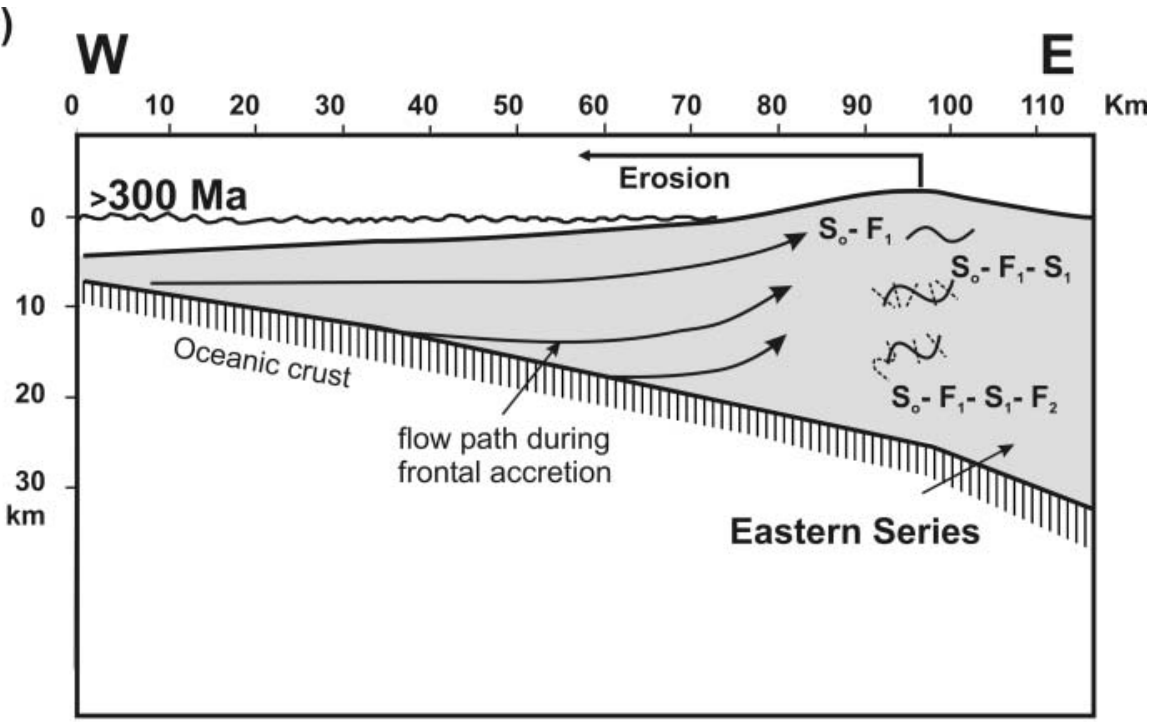

(b) $\mathbf{W}$

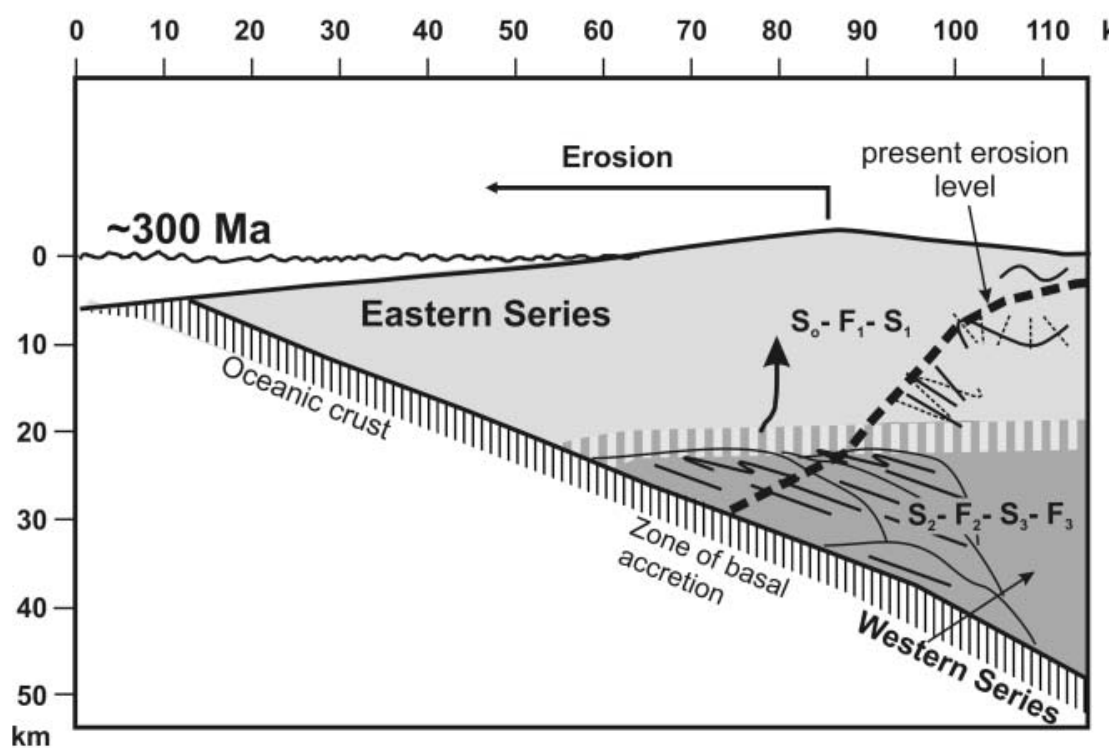

Fig. 10. Proposed tectonic evolution of Late Palaeozoic accretionary wedge illustrated by flow-line model of Feehan \& Brandon (1999) and Ring et al. (1999). (a) Frontal accretion of the Eastern Series before $300 \mathrm{Ma}$. The material is shuffled horizontally through the wedge and bedding is deformed by upright folds caused by horizontal east-west shortening. (b) Change to basal accretion as evidenced by the c. $300 \mathrm{Ma}$ ages for high-pressure metamorphism in the Western Series. The change in the mode of accretion caused a fundamental change in the flow field and caused vertical shortening as indicated by the subhorizontal foliation. The consistent orientation of the underplating-related stretching lineations and west-vergent folding in the deeper parts of wedge suggest considerable basal traction and also increased imbrication of slices of oceanic crust from the downgoing plate. The lowermost rocks of the Eastern Series were affected by basal traction and the $\mathrm{F}_{2}$ folds are west-vergent near the contact with the Western Series. It should be noted that in the Western Series rocks only $F_{2}, S_{2}, F_{3}$ and $\mathrm{S}_{3}$ structures have been observed and $\mathrm{S}_{1}$ occurs only as relicts in these rocks. The pressure of the metamorphic overprint of $c$. 3 kbar indicates that Eastern Series was in the upper crust (10-12 km depth). 


\section{References}

Aguirre, L., Hervé, F. \& Godoy, E. 1972. Distribution of metamorphic facies in Chile: an outline. Krystallinikum, 9, 7-19.

Bolhar, R. \& Ring, U. 2001. Deformation history of Yolla Bolly terrane rocks at Leech Lake Mountain, Eastern belt, Franciscan subduction complex. Geological Society of America Bulletin, 113, 181-195.

BRANDON, M.T. 1995. Representation of geologic strain data in strain-magnitude space. Journal of Structural Geology, 17, 1375-1385.

Brandon, M.T. \& Calderwood, A.R. 1990. High-pressure metamorphism and uplift of the Olympic subduction complex. Geology, 12, 1252-1255.

Cowan, D.S. 1974. Deformation and metamorphism of the Franciscan subduction zone complex northwest of Pacheco Pass, California. Geological Society of America Bulletin, 85, 1623-1634.

Davidson, J., Mrodozis, C., Godoy, E., Hervé, F., Pankhurst, R.J. \& Brook, M. 1987. Late accretionary complexes on the Gondwana margin of southern Chile: evidence from the Chonos Archipelago. In: McKenzie, G.D. (ed.) Gondwana Six: Structure, Tectonics and Geophysics. Geophysical Monographs, American Geophysical Union, 40, 221-227.

Deckert, H., Ring, U. \& Mortimer, N. 2002. Tectonic significance of Cretaceous bivergent extensional shear zones in the Torlesse accretionary wedge, central Otago Schist, New Zealand. New Zealand Journal of Geology and Geophysics, 45, 537-547.

ERNST, W.G. 1975. Systematics of large-scale tectonics and age progressions in Alpine and Circum-Pacific blueschist belts. Tectonophysics, 26, 229-246.

Feehan, J.G. \& Brandon, M.T. 1999. Contribution of ductile flow to exhumation of low-temperature, high-pressure metamorphic rocks, San Juan-Cascade nappes, NW Washington state. Journal of Geophysical Reasearch, 104, 10883-10902.

Glodny, J., Lohrmann, J., Echtler, H., GräFe, K., Seifert, W., Collao, S. \& FigUEROA, O. 2005. Internal dynamics of a paleoaccretionary wedge: insights from combined isotope tectonochronology and sandbox modelling of the south-central Chilean forearc. Earth and Planetary Science Letters, 231, 23-39.

Godoy, E. 1970. Estudio petrográfico del granito de Constitución y su aureola de metamorfismo de contacto. BSc thesis, Universidad de Chile, Santiago.

Godoy, E. \& Kato, T. 1990. Late Paleozoic serpentinites and mafic schists from the Coast Range accretionary complex, Central Chile: their relation to aeromagnetic anomalies. Geologische Rundschau, 79, 121-130.

GonZÁlez-BonoRino, F. 1971. Metamorphism of the crystalline basement of central Chile. Journal of Petrology, 12, 149-175.

Hervé, F. 1988. Late Paleozoic subduction and accretion in Southern Chile. Episodes, 11, 183-188.

Hervé, F., Munizaga, F., Parada, M.A., Brook, M., Pankhurst, R.J., Snelling, N.J. \& Drake, R. 1988. Granitoids of the coast range of central Chile: geochronology and geologic setting. Journal of South American Earth Sciences, 1, 185-194.

Hervé, F., Demant, A., Ramos, V.A., Pankhurst, R.J. \& Suárez, M. 2000. The Southern Andes. In: Cordani, U.G., Milani, E.J., Thomaz Filho, A. \& CAmpos, D.A. (eds) Tectonic Evolution of South America. 31st International Geological Congress, Rio de Janeiro, 605-634.

Kato, T.T. 1985. Pre-Andean orogenesis in the Coast Ranges of Central Chile. Geological Society of America Bulletin, 96, 918-924.

Lucassen, F., Trumbull, R., Franz, G., Creixell, C., Vasquez, P., Romer, R.L. \& Figueroa, O. 2004. Distinguishing crustal recycling and juvenile additions at active continental margins: the Paleozoic to recent compositional evolution of the Chilean continental margin $\left(36^{\circ}-41^{\circ} \mathrm{S}\right)$. Journal of South American Earth Sciences, 17, 103-119.

MARCH, A. 1932. Mathematische Theorie der Regelung nach der Korngestalt affiner Deformation. Zeitschrift für Kristallographie, 81, 285-297.

Marioth, R. 2001. Charakterisierung und Quantifizierung thermischer und diagenetischer Prozesse im karbonischen Akkretionsprisma in Nordchile. $\mathrm{PhD}$ thesis, University of Heidelberg.

Miyashiro, A. 1973. Metamorphism and Metamorphic Belts. Allen \& Unwin, London.

Moore, J.C. \& Allwardt, A. 1980. Progressive deformation of a Tertiary trench slope, Kodiak Island, Alaska. Journal of Geophysical Research, 85, 47414756.

MortimER, N. 1993. Jurassic tectonic history of the Otago schist, New Zealand. Tectonics, 12, 237-244.

NADAI, A. 1950. Theory of Flow and Fracture of Solids, 2nd. McGraw-Hill, New York, 1.

Oertel, G. 1983. The relationship of strain and preferred orientation of phyllosilicate grains in rocks - a review. Tectonophysics, 100, 413-447.

OwENS, W.H. 1984. The calculation of a best-fit ellipsoid from elliptical sections on arbitrarily orientated planes. Journal of Structural Geology, 6, 571-578.

Peach, H. \& Lisle, R. 1979. A Fortran IV program for the analysis of tectonic strain using deformed elliptical markers. Computers and Geosciences, 5, $325-334$.

Platt, J.P. 1975. Metamorphic and deformational processes in the Franciscan Complex: California, some insights from the Catalina schist terrane. Geological Society of America Bulletin, 86, 1337-1347.

Press, W.H., Flannery, B.P., Teukolsky, S.A. \& Vetterling, W.T. 1986. Numerical Recipes. The Art of Scientific Computating. Cambridge University Press, Cambridge, 526-528.

Ramsay, J.G. 1967. Folding and Fracturing of Rocks. McGraw-Hill, New York.

Ramsay, J.G. \& Huber, M.I. 1983. The Techniques of Modern Structural Geology, Volume 1: Strain Analysis. Academic Press, New York.

Ring, U. \& Brandon, M.T. 1994. Kinematic data for the Coast Range fault and implications for exhumation of the Franciscan complex. Geology, 22, 735-738.

Ring, U. \& Brandon, M.T. 1999. Ductile strain, coaxial deformation and mass loss in the Franciscan complex: implications for exhumation processes in subduction zones. In: RING, U. \& BRANDON, M.T. (eds) Exhumation Processes: Normal Faulting, Ductile Flow and Erosion. Geological Society, London, Special Publications, 154, 55-86.

Ring, U. \& Brandon, M.T. 2006. The tectonic evolution of the Franciscan subduction complex: implications for the exhumation of high-pressure rocks in subduction-related accretionary wedges. Geological Society of America, Special Paper, in press.

Ring, U. \& RichteR, P.P. 2004. Normal faulting at convergent plate boundaries: the Del Puerto Canyon shear zone in the Franciscan subduction complex revisited. Tectonics, 23, 1022, doi: 10.1029/2002TC001476.

Ring, U., Brandon, M.T., Willett, S. \& Lister, G.S. 1999. Exhumation processes. In: Ring, U., Brandon, M.T., Lister, G.S. \& Willett, S. (eds) Exhumation Processes: Normal Faulting, Ductile Flow and Erosion. Geological Society, London, Special Publications, 154, 1-27.

Sнiмamoto, T. \& IKEDA, Y. 1976. A simple algebraic method for strain estimation from deformed ellipsoidal objects. 1. Basic theory. Tectonophysics, 36, 315337.

Suppe, J. 1973. Geology of the Leech Lake Mountain-Ball Mountain Region, California: a Cross-section of the Northeastern Franciscan Belt and its Tectonic Implications. University of California Press, Berkeley.

SuPPE, J. 1978. Cross section across southern part of northern Coast Ranges and Sacramento Valley, California (1:250000). Geological Society of America, Map and Chart Series, MC-28B

TulLis, T.E. \& WooD, D.S. 1975. Correlation of finite strain from both reduction bodies and preferred orientation of mica in slate from Wales. Geological Society of America Bulletin, 86, 632-638.

WiLLNER, A.P. 2005. Pressure-temperature evolution of a Late Palaeozoic paired metamorphic belt in North-Central Chile $\left(34^{\circ}-35^{\circ} 30^{\prime} \mathrm{S}\right)$. Journal of Petrology, 46, 1805-1833.

Willner, A.P., Hervé, F. \& Massonne, H.-J. 2000. Mineral chemistry and pressure-temperature evolution of two contrasting high-pressure-low-temperature belts in the Chonos Archipelago, Southern Chile. Journal of Petrology, 41, 309-330.

Willner, A.P., Thomson, S.N., Kröner, A., Wartho, J.-A., Wijbrans, J.R. \& HERVÉ, F. 2005. Time markers for the evolution and exhumation history of a Late Palaeozoic paired metamorphic belt in North-Central Chile $\left(34^{\circ}-\right.$ $\left.35^{\circ} 30^{\prime} \mathrm{S}\right)$. Journal of Petrology, 46, 1835-1855.

Wood, D.S. \& OerTel, G. 1980. Deformation in the Cambrian slate belt of Wales. Journal of Geology, 88, 309-326. 